\title{
Thogoto Virus: a Hitherto Undescribed Agent Isolated from Ticks in Kenya
}

\author{
By D. A. HAIG,* J. P. WOODALL aNd D. DANSKIN \\ From the Veterinary Research Laboratory, Kabete, Kenya, and the \\ East African Virus Research Institute, Entebbe, Uganda
}

(Received 22 September 1964)

\begin{abstract}
SUMMARY
A filterable ether-sensitive agent was isolated from a pool of ticks collected during September 1960 from cattle in the Thogoto forest near Nairobi, Kenya. The pool consisted of Boophilus decoloratus, Rhipicephalus appendiculatus, $\boldsymbol{R}$. simus and $\boldsymbol{R}$. evertsi. The agent is apparently antigenically unrelated to 75 known arboviruses and is considered to be a previously undescribed virus, which has been named Thogoto virus. High degrees of immunity were found in livestock in some areas of East Africa.
\end{abstract}

\section{INTRODUCTION}

Ticks are known to be vectors of human and domestic animal virus infections in various parts of the world (Smith, 1962; Work, 1963). The tick-borne viruses which cause Russian spring-summer encephalitis and related encephalitic syndromes belong to a subgroup of Casals's serological Group B of the arboviruses (Casals \& Brown, 1954). Two other Group B viruses are carried by Ixodid ticks : Powassan virus, which causes encephalitis in man in North America, and louping-ill virus, which produces a severe disease in sheep and occasional illness in cattle and man in Great Britain. On the other hand, Colorado tick fever virus and Kemerovo virus (Chumakov et al. 1963), which have been isolated from Ixodid ticks and which cause human disease in North America and the U.S.S.R. respectively, are not serologically related to Group B or to any other of the presently described arbovirus groups. The same applies to the previously known tick-borne viruses of Africa: Nairobi sheep disease, AR 492, Quaranfil, Chenuda and Nyamanini. These show by current techniques neither serological interrelationship nor cross-relationship with any other arbovirus. Nairobi sheep disease virus has been isolated from sheep, goats and Rhipicephalus appendiculatus during epizootics (Montgomery, 1917; Daubney \& Hudson, 1931); AR 492 was isolated from $R$. sanguineus from the Sudan, Quaranfil and Chenuda from Argasid ticks in Egypt; Quaranfil has also been isolated from febrile children in Egypt, but no vertebrate involvement with either AR 492 or Chenuda virus has yet been demonstrated (Dr R. M. Taylor, personal communication). Nyamanini virus has been isolated from the cattle egret Bubulcus ibis (Linn.) and Argas arboreus collected in a heronry of cattle egrets and other birds in South Africa, and antibodies have been found in man, goats and a donkey

* Present address: Institute for Research on Animal Diseases (A.R.C.), Compton, Newbury, Berks. 
(Dr B. M. McIntosh, personal communication). The present paper reports the isolation in Africa of another virus from Ixodid ticks, which is not serologically related to any other arbovirus so far tested, and to which high rates of antibody have been found in livestock in some parts of East Africa.

\section{METHODS}

Six steers were treated with insecticides and placed in the Thogoto forest in the Dagoretti-Ngong area on the outskirts of Nairobi, at an altitude of about $5600 \mathrm{ft}$. This forest was under the control of the Kenya forestry department and usually cattle were not permitted to enter the area.

Ticks. Ticks were collected daily by hand from the cattle into dry test tubes, during the latter half of 1960 . They were delivered to the laboratory every 2 or 3 days. After identification they were pooled, usually by species but occasionally as a day's harvest. Each lot was then macerated with sand in a mortar and suspended in a balanced salt solution; about $1 \mathrm{ml}$. of solution was allowed for each tick. The supernatant fluid obtained by centrifugation at $2000 \mathrm{rev} . / \mathrm{min}$. for $15 \mathrm{~min}$. was allowed to stand for $\mathbf{3 0} \mathrm{min}$. at room temperature; adult mice were then injected intraperitoneally (i.p.) with $0.1 \mathrm{ml}$. and infant mice intracerebrally (i.c.) with $0.01 \mathrm{ml}$. of the fluid.

Diluents. Hanks balanced salt solution containing 1000 i.u. penicillin, $1000 \mu \mathrm{g}$. streptomycin, 300 i.u. neomycin and $300 \mu \mathrm{g}$. mycostatin $/ \mathrm{ml}$., was used for initial suspension. Subsequent dilutions of animal tissues were made in $5 \%$ peptone water to which was added 500 i.u. penicillin and $500 \mu \mathrm{g}$. streptomycin $/ \mathrm{ml}$.

For the neutralization tests, the virus diluent was $0.75 \%$ bovine plasma albumin (Armour fraction V) in phosphate buffered saline ( $\mathrm{pH} 7 \cdot 4)$.

Mice. For isolation and early passage white mice from the Kabete colony were used. For identification studies, mice of the Entebbe colony were used; these are an albino Swiss strain derived from the stock of Carworth Farms, New York. Infant mice were inoculated at 2-3 days of age; adult mice when about 6 weeks old.

Hamsters. Golden Syrian hamsters were supplied from the Kabete laboratory colony soon after weaning. All injections $(1 \mathrm{ml}$.) were made intraperitoneally.

Sheep. These were of mixed breed obtained from the Kabete laboratory farm or bought from outside sources.

Serological tests. Haemagglutination inhibition (HI) tests were done according to the methods of Clarke \& Casals (1958). A haemagglutinating antigen was prepared from the livers of infected infant mice by sucrose acetone extraction, followed by fluorocarbon extraction to improve the cell pattern of the test. This antigen was used at $4^{\circ}$ and $\mathrm{pH} 5 \cdot 8$. Several attempts to produce an antigen from mouse brain were unsuccessful.

Complement fixation (CF) tests used the same liver antigen as above, and followed the method of Weinbren (1958).

Protection tests (PT) were done in 1- to 3-day mice. These were inoculated intracerebrally with $0.02 \mathrm{ml}$. of mixtures of mouse-brain virus (diluted to contain a calculated $100 \mathrm{LD} 50$ and equal volumes of the undiluted test serum. These mixtures had been previously incubated at $37^{\circ}$ for $1 \mathrm{hr}$. 


\section{RESULTS}

\section{Isolations}

Infective agents were obtained from two lots of ticks collected during September 1960. Nothing was isolated from 25 pools of ticks collected later that year, comprising 16 pools of Boophilus decoloratus (Koch, 1844), 3 of Ixodes sp., 2 of Rhipicephalus kochi (Donitz, 1905), 1 of $R$. appendiculatus (Newmann, 1901) and 3 pools in which $R$. evertsi (Newmann, 1897), $R$. simus (Koch, 1844) and $R$. appendiculatus were mixed.

The first pool ('Thogoto $2 \mathrm{~A}$ ') from which a virus was isolated contained: 95 $B$. decoloratus, $14 R$. appendiculatus, $14 R$. simus, and $5 R$. evertsi. These ticks were collected on 4 September 1960. Of twelve infant mice injected with a suspension of these ticks, seven were moribund on the 5th day while the remaining five were obviously sick; the adult mice showed no apparent reaction. Brains from two of the sick mice were diluted 1/100 and injected into other infant mice as well as adult mice and hamsters. The infant mice became sick on the 3rd and 4th days, the adult mice injected intracerebrally or intraperitoneally reacted sporadically from the 4th to the 8th day, while the hamsters were acutely sick on the 3rd day. The strain was passaged serially in groups of infant mice by the cerebral route. By the 15th infant mouse-brain passage, the virus titred $6.0 \log _{10} \mathrm{LD} 50 / 0.02 \mathrm{ml}$. by both the i.c. and i.p. routes, and deaths were occurring on the 3 rd post-inoculation day.

Because of the uniformity of the reaction in hamsters passage was continued in this animal, with brain and spleen as inoculum. Severe illness with death followed in 2-3 days. A titration of an infected spleen was positive at a dilution of $10^{-6}$, the highest dilution tested.

At autopsy it was observed that the brain, liver, and small intestine of these hamsters were markedly hyperaemic. Histopathological examination revealed no other changes in the viscera, but degeneration, particularly of the neurons, was observed in the cerebellum, where Purkinje cells were markedly affected. In addition, there was pronounced oedema with distension of the Virchow-Robin spaces. No perivascular cuffing was seen.

A $1 \%(w / v)$ suspension of hamster spleen was passed through a Ford S.B. Sterimat (R). Two hamsters injected with this filtrate reacted on the 3rd and 4th days whereas two which received unfiltered material died on the 3rd day.

A $1 \%(w / v)$ mouse-brain suspension in normal saline passed through Gradocol membranes of average pore diameter (apd) 680 and $410 \mathrm{~m} \mu$, but not through one of $210 \mathrm{~m} \mu$. These membranes were supplied by Dr F. Himmelweit of the WrightFleming Institute of Microbiology, St Mary's Hospital, London.

A $1 \%(w / v)$ hamster spleen suspension was exposed to ether by the method advocated by Andrewes \& Horstmann (1949). Titration in hamsters showed untreated material to be infective at a dilution of at least $10^{-5}$, but the treated material did not produce any apparent reaction.

Two sheep were injected intravenously with $5 \mathrm{ml}$. of $10 \%(\mathrm{v} / \mathrm{v})$ brain suspension from the 5th infant mouse passage. Both sheep showed a thermal reaction on the 2nd and 3rd days, with temperatures up to $106^{\circ} \mathrm{F}$. Blood taken at the height of the febrile reaction was injected into infant mice, hamsters and other sheep. In all these animals characteristic reactions were produced. 
A pool ('Thogoto 3B') of 50 Boophilus decoloratus ticks, collected from the same cattle on 9 September 1960, was treated in the same way as the previous pool and injected into fourteen infant mice. On the 6th day three were sick, and on the 7th day one more, while the remainder appeared well on the 8th day when they were killed. The brain material was passed to other infant mice, which died sporadically from the 2nd to 6th days. From then on passages were continued in hamsters in which deaths occurred on the 2nd and 3rd days at each passage.

\section{Identification}

Strain Thogoto $2 \mathrm{~A}$ was compared with 75 known arboviruses, 4 mouse viruses and 2 other viruses, each by one or more serological tests, with the results shown in Table 1.

\section{Table 1. Viruses used in the serological testing of Thogoto virus}

There was no reaction between Thogoto virus and any of the viruses listed below in haemagglutination inhibition tests or in complement fixation tests or in protection tests: in many cases more than one type of test was carried out.

Group A
Aura
Bebaru
Chikungunya
Eastern equine
encephalitis
Getah
Mayaro
Middelburg
Ndumu
O'nyong-nyong
Semliki
Sindbis
Venezuelan equine
encephalitis
Western equine
encephalitis
Group B (mosquito)
Dengue 1
Dengue 2
Dengue 4
H 336
IPD A/249
Japanese B encephalitis
Murray valley encephalitis
Ntaya
St Louis encephalitis
Spondweni
Uganda S
Usutu
Wesselsbron
West Nile
Yellow fever
Zika

Group B (tick)
Powassan
Russian spring-summer
encephalitis (other)
Entebbe Bat
Group C
Apeu
Caraparu
Marituba
Oriboca

Bunyamwera group Bunyamwera Germiston Ilesha

California complex

California

Lumbo

Tahyna

Simbu group

Akabane

Ingwavuma

Manzanilla

Sathuperi

Simbu

Bwamba group

Bwamba

Pongola

Bakau group

Bakau

Ketapah
Ungrouped African horse

Bluetongue

Koongol

Lagos Bat

Mossuril

Nyando

Rift Valley

Sandfly fever (Naples)

Sandfly fever (Sicily)

Witwatersrand (tick)

AR 492

Chenuda

Colorado tick

Dalcairnie

Dry Tortugas

IG 619

IG 690

IG 700

Kaisodi

Kemerovo

Nairobi sheep

Nyamanini

Quaranfil

Silverwater

Other viruses

Encephalomyocarditis

Lymphocytic

choriomeningitis

reovirus (3?)*

Semunyat

Theiler's FA

Theiler's GD 7

* Bell et al. (1964).

$\dagger$ Weinbren et al. (1959).

\section{Serological survey}

Mouse protection tests were done with 48 human sera and 130 domestic animal sera; the latter were heat inactivated at $56^{\circ}$ for $30 \mathrm{~min}$. before testing. The human sera were from donors living in various parts of the Rift Valley in Kenya, between 
Lakes Naivasha and Baringo, at altitudes ranging from 3000 to $8000 \mathrm{ft}$. above sealevel. None was protective against a challenge of $11 \mathrm{LD} 50$ doses. Some of the donors lived in close contact with livestock which included a proportion of immune animals (see below). Forty of these human sera were also screened against Thogoto haemagglutinating antigen, with negative results.

The domestic animal sera were collected in the same area of Kenya, with the addition of fifteen cattle sera from Entebbe, Uganda. The Nakuru cattle and sheep were pedigree exotic animals from farms at altitudes above $7000 \mathrm{ft}$. The Marigat livestock were local strains belonging to Samburu tribesmen, living at about $\mathbf{3 0 0 0} \mathrm{ft}$. The Entebbe cattle were crossbreds living at $4000 \mathrm{ft}$.

The numbers of sera protective against a challenge of $60 \mathrm{LD} 50$ doses were as follows:

$\begin{array}{lccc} & \text { Nakuru } & \text { Marigat } & \text { Entebbe } \\ \text { Cattle } & 0 / 33 & 12 / 20 & 15 / 15 \\ \text { Sheep } & 0 / 38 & 3 / 9 & - \\ \text { Goats } & - & 1 / 15 & -\end{array}$

\section{DISCUSSION}

A virus (Thogoto $2 \mathrm{~A}$ ) has been isolated from a pool of ticks including Boophilus decoloratus, Rhipicephalus appendiculatus, $\boldsymbol{R}$. simus and $\boldsymbol{R}$. evertsi collected from cattle in the Thogoto forest near Nairobi, Kenya. A second isolate (Thogoto 3B) was made soon afterwards from a group of $B$. decoloratus obtained from the same locality. While this latter isolate resembled the first, it was not compared serologically with it. Because the isolation was made while work on the first was in progress, it is not possible to exclude an accidental laboratory cross-infection and it can therefore only be considered a possibility that $\boldsymbol{B}$. decoloratus ticks are the actual carriers of infection.

The virus has been tested against all presently characterized African arboviruses, and other arboviruses whose distribution is not known to include Africa, in particular all presently known serologically ungrouped isolates from ticks. There was no haemagglutination-inhibition relationship with Russian spring-summer encephalitis antigen or any other of Casals's serological Group B, which effectively excludes that group of tick-borne agents. There was also no relationship with Nairobi sheep disease, the only other known African tick-borne virus disease of livestock. The only arboviruses against which the virus has not been tested are some isolates from the Americas and Australasia, and it seems unlikely that any of these will be found to be related to it; none was isolated from ticks. The results of the serological surveys do not indicate any involvement of man with the virus, but do suggest infection of livestock farmed at lower altitudes in Kenya and Uganda, where tick infestation is considerable.

We wish to thank the Director of Veterinary Services, Kenya, for permission to publish this paper, Mr M. L. Burdin for the histological examination, Mr P. NapierBax for collecting the ticks and Mr B. T. Parsons for their identification. Many of the HI and CF tests were done by Dr J. Casals (Rockefeller Foundation Virus Laboratories, New York). Some of these tests were done by one of us (J.P.W.) at 
the Rockefeller Foundation Laboratories whilst in receipt of a Rockefeller Foundation travel grant. Dr M. C. Williams and Mr A. H. Revell of the East African Virus Research Institute collected the human and domestic animal survey sera.

\section{REFERENCES}

Andrewes, C. H. \& Horstmann, D. M. (1949). The susceptibility of viruses to ethyl ether. J. gen. Microbiol. 3, 290.

Bell, T. M., Massie, A., Ross, M. G. R. \& Williams, M. C. (1964). Isolation of a reovirus from a case of Burkitt's lymphoma. Brit. med. J. i, 1212.

Casals, J. \& Brown, L. V. (1954). Hemagglutination with arthropod-borne viruses. $J$. exp. Med. 99, 429.

Chumakov, M. P., Sarmanova, E. S., Bychkova, M. B., Bannova, G. G., Pivanova, G. P., Karpovich, L. G., Izotov, V. K. \& RzHakHova, O. E. (1963). Vopr. Virusol. 8, 440, cited in Biol. Abstr. (1964), 45, (7) $2385,29542$.

Clarke, D. H. \& Casals, J. (1958). Techniques for hemagglutination-inhibition with arthropod-borne viruses. Am. J. trop. Med. Hyg. 7, 561.

Daubney, R. \& Hudson, J. R. (1931). Nairobi sheep disease. Parasitology, 23, 507.

Montgomery, E. (1917). On a tick-borne gastro-enteritis of sheep and goats occurring in British East Africa. J. comp. Path. 30, 28.

Sмrtн, C. E. G. (1962). Ticks and viruses. Symp. zool. Soc. Lond. 6, 199.

Weinbren, M. P. (1958). An improved method for the complement fixation test using small quantities of reagents. E. Afr. Virus Res. Inst. Rep. 1957-58, 8, 38.

Weinbren, M. P., Knight, E. M., Eluice, J. M. \& Hewitt, L. E. (1959). Hitherto unknown strains of virus isolated from human serum. E. Afr. Virus Res. Inst. Rep. 1958-59, 9, 7.

Work, T. H. (1963). Tick-borne viruses. Bull. Wld Hlth Org. 29, 59. 